\title{
The rational cure for prereproductive stress syndrome revisited
}

\section{Häyry}

If it is irrational to allow the worst outcome of our actions, and if it is immoral to cause suffering, then it is irrational and immoral to have children.

recently published in this journal a paper, entitled A rational cure for prereproductive stress syndrome, and was happy to see that three colleaguesRebecca Bennett, Søren Holm, and Sahin Aksoy-had taken the time to critically examine it. This gave me an opportunity to briefly revisit the topic, and to clarify some of the arguments I put forward.

\section{THE IRRATIONALITY OF HAVING CHILDREN}

In my paper, A rational cure for prereproductive stress syndrome, ${ }^{1}$ I claimed that it is irrational to have children,

- if (a) it is irrational to deliberately allow the worst outcome of our actions in a given situation,

- and if (b) to have children allows this.

I argued that having children allows the worst outcome of our reproductive choices (the creation of a possibly bad life, where the alternative is no life),

- if (c) it makes good sense to restrict the analysis to the comparative value of life versus non-existence of possible future individuals, as experienced by themselves,

- and if (d) there are individuals who genuinely would prefer non-existence to their own life.

My practical conclusion in the paper was modest: (e) "Possible parents could be told that, according to at least one philosopher, it would be all right for them not to reproduce at all."1 This was my suggested "rational cure for prereproductive stress syndrome".

\section{“NOT STRONGLY IRRATIONAL"}

Holm argues against (a) that it is not irrational to deliberately allow a low probability of the worst outcome. ${ }^{2} \mathrm{He}$ starts from the premise that to make my argument work I would need to regard the maximin rule-the rule specified in claim (a)-as the only criterion of rationality. If I do so, however, I should never, in fear of micro-organisms, eat food that has not been fully sterilised in an autoclave-something that Holm seems to think would be ludicrous. On the other hand, if I do not regard the maximin rule as the only criterion of rationality, I cannot defend directive counselling against having children.

I have a very simple countercomment to this. I do not regard the maximin rule as the only definition of rationality. Nor do I need to do so, because I do not advocate directive counselling - a choice I hoped would be clear from the cautious formulation of conclusion (e). My apologies, if I have expressed myself in unclear terms.

\section{“LIFE CANNOT BE THE WORST OUTCOME"}

Aksoy argues against (b) that having children cannot bring about the worst outcome, because the worst possible outcome of reproductive choices is always non-existence. ${ }^{3}$ He refers to his own previously formulated view, ${ }^{4}$ according to which existence "is essential and prerequisite to everything good or bad, and deserves to be protected and respected". ${ }^{3}$ He also quotes Spinoza, who in his work published in 1677 wrote: "No one can desire to be happy, to act well and live well, who does not at the same time desire to be, to act, and to live, that is to say, actually to exist". ${ }^{3}$

My primary reason for not being impressed by these statements in the present context is that they do not address choices before a being is or is not brought into existence. I can fully agree with Aksoy that human existence, once it is "here", so to speak, is the basis of all experiences. I can also agree with Spinoza that being alive precedes desires

\section{Abstract}

If it is irrational to allow the worst outcome of our actions, and if it is immoral to cause suffering, then it is irrational and immoral to have children. concerning the content of one's life (if this is what he meant): but I fail to see the relevance of these statements to the choice to reproduce or not to reproduce. All they demonstrate is that as the foundation of our experiences, life can have positive instrumental value to us if our experiences are good. By the same token, it can have negative instrumental value to us if our experiences are bad. It does not, however, have any value, good or bad, when it is not present.

\section{"IT IS RATIONAL TO HAVE SAVIOUR SIBLINGS"}

Bennett notes against my claim (c) that in certain circumstances it does seem irrational to ignore the interests of a potential child's existing siblings. ${ }^{5}$ A case in point is when these siblings suffer horribly from conditions that could be cured or substantially alleviated by tissue transplants from the new individuals. It would seem rational, according to my adopted account, to produce these "saviour siblings". By doing so we could remove certain suffering by allowing only a slight possibility of suffering-surely an acceptable trade off?

Well, no. In fact, such trade offs are not in line with the maximin rule. The remark is good from the viewpoint of maximising expected utility, which is another feasible way of construing what rationality means. ${ }^{67}$ Because, however, the worst possible outcome of creating "saviour siblings" is that there will be, in the end, two lives that those living them would prefer not to have (instead of just the already existing one), maximin rationality does not support this choice.

\section{THE IMMORALITY OF HAVING CHILDREN}

I also claimed in my paper that it is immoral to have children:

- if (f) it is immoral to bring about avoidable suffering,

- and if (g) having children has this effect.

I took the first statement to be self evidently true, and supported the second by specifying two senses in which it can be said to be true. Having children brings about avoidable suffering

- in the sense that (h) all human beings suffer at some point in their lives, 
- and in the sense that (j) potential parents cannot guarantee that their child's life would not become at some point in time (physically, mentally, or socially) overwhelmingly miserable.

The truth of these statements was not contested by my critics, although their ethical implications were.

My practical conclusion from these premises was even more modest than my inference from the analysis of rationality: (k) "In principle, and in an equal discussion between competent participants, my moral views may entitle me to reproach individuals who decide, or have decided, to have children. There is, however, seldom much point in my doing so."

\section{“IT IS IN (NEARLY) EVERYBODY'S INTEREST TO EXIST"}

Aksoy and Bennett both dispute my claim (f) - that it is immoral to bring about avoidable suffering-by arguing that it would be good to all, or at least most, individuals, to exist, and therefore always morally acceptable to help them in this endeavour, despite the suffering produced.

According to Aksoy, it is right to allow any suffering our potential children can experience, because existence is in and of itself valuable, and non-existence is the paragon of evil. In his view, it is "immoral to 'sentence' someone to nonexistence while you have the chance to bring them into life" ${ }^{\prime 3}$ Bennett, in her turn, argues that it is permissible to bring about some suffering, if good things in life depend on this. In her words, it "is in the interest of any child whose life will be likely worth living overall, that he or she is brought to birth". $^{\prime 5}$

My main conceptual difficulty with these critiques is that I do not know who Aksoy and Bennett are talking about. Who exactly is the absent someone who is sentenced to non-existence; and who precisely is the unborn child whose interests would be served by bringing her to birth? How can we attribute experiences and interests to beings who have not existed in the past, do not exist now, and will possibly never exist in the future?

Apart from this metaphysical problem, there are a couple of normative issues that I would like to raise.

Aksoy seems to say that even individuals whose lives would be utterly miserable-filled with suffering and nothing else-must be brought into existence, when we have that chance. If this is his message, I disagree and so do many others. ${ }^{589}$ I think that it would be inhumane to force suffering human beings to live. Aksoy's view also implies that we should spend our entire lives trying to make babies. Women should aim to be with child all the time, and men should probably focus on perfecting the techniques of ectogenesis and male pregnancy. This is not an impossible idea, of course, but it is not one that is likely to have wide popularity, either.

Bennett, on the other hand, resorts to the language of "worthwhile lives" (an expression, by the way, which is not used in my original paper). This is undoubtedly a good move in that it helps her to avoid the criticism levelled at Aksoy's more stringent view. It is not easy, however, to draw the line between "worthwhile" and "unworthwhile" lives in a universally acknowledged, or even widely accepted, way.

So although Aksoy can be accused of committing himself to an absurdly stern view, Bennett defends a position that seems to require further specifications.

\section{SUMMARY AND CONCLUSIONS}

I have argued in this response to my critics that if it is irrational to allow the worst outcome of our actions, and if it is immoral to cause suffering, then it is irrational and immoral to have children. I have also spelled out the premises of my argument, and claimed that they remain intact against the main objections presented by my critics.

I have not argued-either here or in the original paper - that the accounts of rationality and morality I have evoked are the only ones. All I have said is that it makes good sense to apply the maximin rule to reproductive choices, in which we can actually refrain from creating beings that we can harm merely by creating them. Nor have I argued-here or originally-that would be parents should be given directive antinatal counselling. All I have implied, by arguing that abstinence is a rational and moral choice, is that would be parents should probably not be given directive pronatal counselling, either.

In the light of these observations, I still believe it would be all right for people not to reproduce: and I still think that people would not be horribly manipulated if someone told them this.

\section{ACKNOWLEDGEMENTS}

This article was produced as a part of the project Ethical and Social Aspects of Bioinformatics (ESABI), financed between 2004 and 2007 by the Academy of Finland (SA 105139). My thanks are due to the academy for its support, to Dr Tuija Takala for her helpful comments, and to Peter Herissone-Kelly for checking my English.

\section{$J$ Med Ethics 2005;31:606-607.}

doi: 10.1136/jme.2005.011684

Correspondence to: M Häyry, Centre for Social Ethics and Policy, Institute of Medicine, Law and Bioethics, School of Law, University of

Manchester, Williamson Building, Oxford

Road, Manchester, M13 9PL, UK; matti.hayry@ manchester.ac.uk

\section{REFERENCES}

1 Häyry M. A rational cure for prereproductive stress syndrome. J Med Ethics 2004;30:377-8.

2 Holm S. Why it is not strongly irrational to have children. J Med Ethics 2004;30:381

3 Aksoy S. Response to: A rational cure for prereproductive stress syndrome. J Med Ethics 2004;30:382-3.

4 Aksoy S. To value life and existence. Eubios J Asian Int Bioethics 1997;7:102-4.

5 Bennett R. Human reproduction: irrational but in most cases morally defensible. J Med Ethics 2004;30:379-80.

6 Savulescu J. Procreative beneficence: why we should select the best children. Bioethics 2001;15:413-26.

7 Häyry $M$. If you must make babies, then at least make the best babies you can? Hum Fertil (Camb) 2004;7:105-12.

8 Bennett R, Harris J. Are there lives not worth living? When is it morally wrong to reproduce? In, Dickenson D, ed. Ethical issues in maternal-fetal' medicine. Cambridge: Cambridge University Press, 2002:321-34.

9 Archard A. Wrongful life. Philosophy 2004;79:403-20. 